\title{
Analisis Kadar Air dan Aroma Blending Kopi Arabika (Coffea arabica L) dan Robusta(Coffea canephora $L$ ) Selama Penyimpanan Dengan Principal Component Analisys (PCA)
}

\author{
Surya Abdul Muttalib1*, J oko Nugraha WK2, Nursigit Bintoro ${ }^{3}$ \\ ${ }^{1}$ Teknik Pertanian, Universitas Mataram, surya15@unram.ac.id \\ ${ }^{2 \& 3}$ Teknik Pertanian, Universitas Gadjah Mada
}

\section{INFO ARTIKEL}

RiwayatArtikel:

Diterima: 05-10-2018

Disetujui : 09-01-2019

\section{Kata Kunci:}

Blending

Principal Component

Analisys

Identifikasi

Kopi

\section{ABSTRAK}

\begin{abstract}
Abstrak:Kopi merupakan komoditas pertanian yang menyumbang devisa terbesar bagi Indonesia dan menjadi komoditas perdagangan nomor dua di dunia. Ekspor kopi Indonesia masih terbatas pada kopi kering gelondongan, belum diolah menjadi barang jadi berupa kopi bubuk. Proses pengolahan menjadi kopi bubuk melalui serangkaian proses penyangraian yang didalamnya terjadi proses fisik dan kimia yang sangat komplek yang mempengaruhi cita rasa dan aroma. Terdapat dua jenis kopi yang berkembang di Indonesia yakni Kopi Arabika dan Robusta dengan karakteristik yang berbeda. Arabika memiliki rasa yang kuat sedangkat robusta memiliki kelebihan dari segi aroma. Jika kedua jenis kopi ini dipadukan maka akan menghasilkan cita rasa dan aroma yang kuat. Penelitian ini bertujuan untuk mengidentifikasi kadar air dan aroma blending kopi arabika dan robusta menggunakan Principal Component Analisys (PCA). PCA pada dasarnya bertujuan untuk menyederhanakan variabel yang diamati dengan cara menyusutkan (mereduksi) dimensinya. Hal ini dilakukan dengan cara menghilangkan korelasi diantara variabel bebas melalui transformasi variabel bebas asal ke variabel baru yang tidak berkorelasi.Identifikasi Aroma blending kopi Arabika dan Robusta dilakukan menggunakan empat buah sensor aroma (electric Nose) yang dipasang secara bersamaan yakni sensor TGS822, TGS825, TGS826 dan TGS2602. Hasil analisis menujukkan PCA mampu mereduksi data dan mengklasifikasi kopi sesuai input kadar air dan aroma selama penyimpanan.
\end{abstract}

\section{A. LATAR BELAKANG}

Terdapat dua jenis kopi yang dibudidayakan di Indonesia yakni jenis kopi arabika dan kopi jenis robusta. Kopi Robusta memiliki kandungan kafein yang lebih tinggi, rasanya lebih netral, serta aroma kopi yang lebih kuat sedangkan kopi arabika memiliki kelebihan dalam hal rasa kopi yang dihasilkan [1]. Sebelum kopi dipergunakan sebagai bahan minuman, terlebih dahulu dilakukan proses roasting. Flavor kopi yang dihasilkan selama proses roasting tergantung dari jenis kopi yang dipergunakan, cara pengolahan biji kopi, mekanisme penyangraian, penghalusan, penyimpanan dan metoda penyeduhannya [2].

Suhu penyangraian sangat berpengaruh terhadap proses kimia yang terjadi di dalam biji kopi. Pada suhu penyangraian $121^{\circ} \mathrm{C}$ maka terjadi penguapan air dan kopi berbau jerami basah. Sampai suhu $149{ }^{\circ} \mathrm{C}$, biji kopi berbau jagung goreng. Suhu $179{ }^{\circ} \mathrm{C}$ gemeretak pertama mulai terjadi. Pada suhu $180{ }^{\circ} \mathrm{C}$ terjadi pirolisis dan dekomposisi termal dalam biji, perubahan ukuran dan bentuk biji. Rekasi-reaksi tersebut menyangkut proses oksidasi, reduksi, hidrolisis, polimerisasi, dekarbosilasi, dan perubahan kimia lainnya. Gula-gula dan protein terpecah menjadi aldehid, alkohol dan asam organik. Karbohidrat lain, terhidrolisis menjadi dekstrin, gulagula sederhana, gliserin dan asam-asam lemak. Setelah mencapai $188{ }^{\circ} \mathrm{C}$ maka sukrosa mulai mencair dan dan terjadi proses karamelisasi dan polimerisasi senyawa rantai panjang, $50 \%$ proses karamelisasi terhenti pada suhu $204^{\circ}$ C. Penghentian sangrai dibawah $207^{\circ} \mathrm{C}$ akan diperoleh tingkat sangrai ringan. Sampai suhu $213{ }^{\circ} \mathrm{C}$, gemeretak pertama selesai, karakteristik cita rasa berdasarkan bahan asal kopi mencapai maksimal. Suhu $218{ }^{\circ} \mathrm{C}$, gemeretak kedua mulai terjadi, karamelisasi mencapai 100 \%. Gemeretak kedua maksimal pada suhu $229{ }^{\circ} \mathrm{C}$, karakteristik kopi berdasarkan bahan baku hilang, diganti karakter sangrai [3].

Blending merupakan suatu proses penambah bahan-bahan lain ke dalam kopi yang bertujuan untuk meningkatkan rasa dari kopi yang dihasilkan. Blending memungkinkan penggantian perubahan selera dalam biji kopi dan penggantian jenis kopi jika ada kesulitan dalam pewarna/harga. Proses pencampuran atau blending dilakukan dengan mencampur biji kopi robusta dan arabika yang sudah di sangrai dan didinginkan terlebih dahulu selama 15 menit. Pencampuran antara kopi robusta dan arabika yang akan dikemas menjadi kopi klasik adalah $50 \%$ berbanding $50 \%$. Proses blending ini dilakukan sebelum digiling atau dihaluskan dengan mesin penghalus sehingga menghasilkan cita rasa yang khas pada kopi [4]. 
Kehilangan aroma dan cita rasa kopi bubuk selama penyimpanan dalam kemasan terutama disebabkan oleh kandungan air dan oksigen di dalam kemasan. Air di dalam kemasan akan menghidrolisa senyawa kimia yang ada di dalam kopi dan menyebabkan bau apek. Keberadaan oksigen di dalam kemasan juga akan menyebabkan penurunan aroma dan cita rasa kopi karena proses oksidasi. Senyawa-senyawa aldehid mudah mengalami proses oksidasi menjadi senyawa asam yang berpengaruh terhadap aroma dan cita rasa kopi [5].

PCA telah banyak digunakan dalam berbagai bidang, diantaranya analisis hubungan kuantitatif antara struktur elektronik dan aktivitas (QSAR) antioksidan dari senyawa turunan flavon/flavonoid. Pada penelitian [6] Principal Component Analysis (PCA) terbukti dapat mengatasi masalah pelanggaran asumsi klasik multikolinearitas tanpa perlu membuang variabel bebas yang berkolinear tinggi. Sehingga setelah diperoleh variabel bebas baru dari hasil reduksi. Setelah dihasilkan variable baru dimungkinkan kedekatan antar variable menjadi suatu system yang digunakan dalam pengelompokan danatau identifikasi kopi yang dihasilkan.

Penelitian ini bertujuan untuk mengidentifikasi kadar air dan aroma blending kopi arabika dan robusta menggunakan Principal Component Analisys (PCA).
PCA pada dasarnya bertujuan untuk menyederhanakan variabel yang diamati dengan cara menyusutkan (mereduksi) dimensinya.

\section{B. METODE PENELITIAN}

\section{Waktu dan Tempat}

Penelitian dilaksanakan pada bulan Oktober 2011 Sampai bulan Januari 2012 di Laboratorium Rekayasa Pengolahan Hasil Pertanian, Laboratorium Teknik Pangan dan Pasca Panen Fakultas Teknologi Pertanian Universitas Gadjah Mada.

\section{Alat dan Bahan}

Alat-alat yang digunakan dalam penelitian ini yaitu : Alat Roasting kopi (Rk-20RCg, putaran 20 rpm), Electrict Nose, Sensor Aroma: sensor TGS822, TGS825, TGS826 dan TGS2602, Thermokopel, Thermodigital, Oven pengering, Timbangan Digital, Stopwatch, Blender , Fungsi : Penghalusan (grinding) kopi sangrai, Alat tulis.

Bahan-bahan yang digunakan dalam penelitian ini yaitu biji kopi dan kemasan (kertas, aluminium voil, gelas).

\section{Alur Penelitian}

Bagan alir penelitian ditunjukkan pada gambar 1.

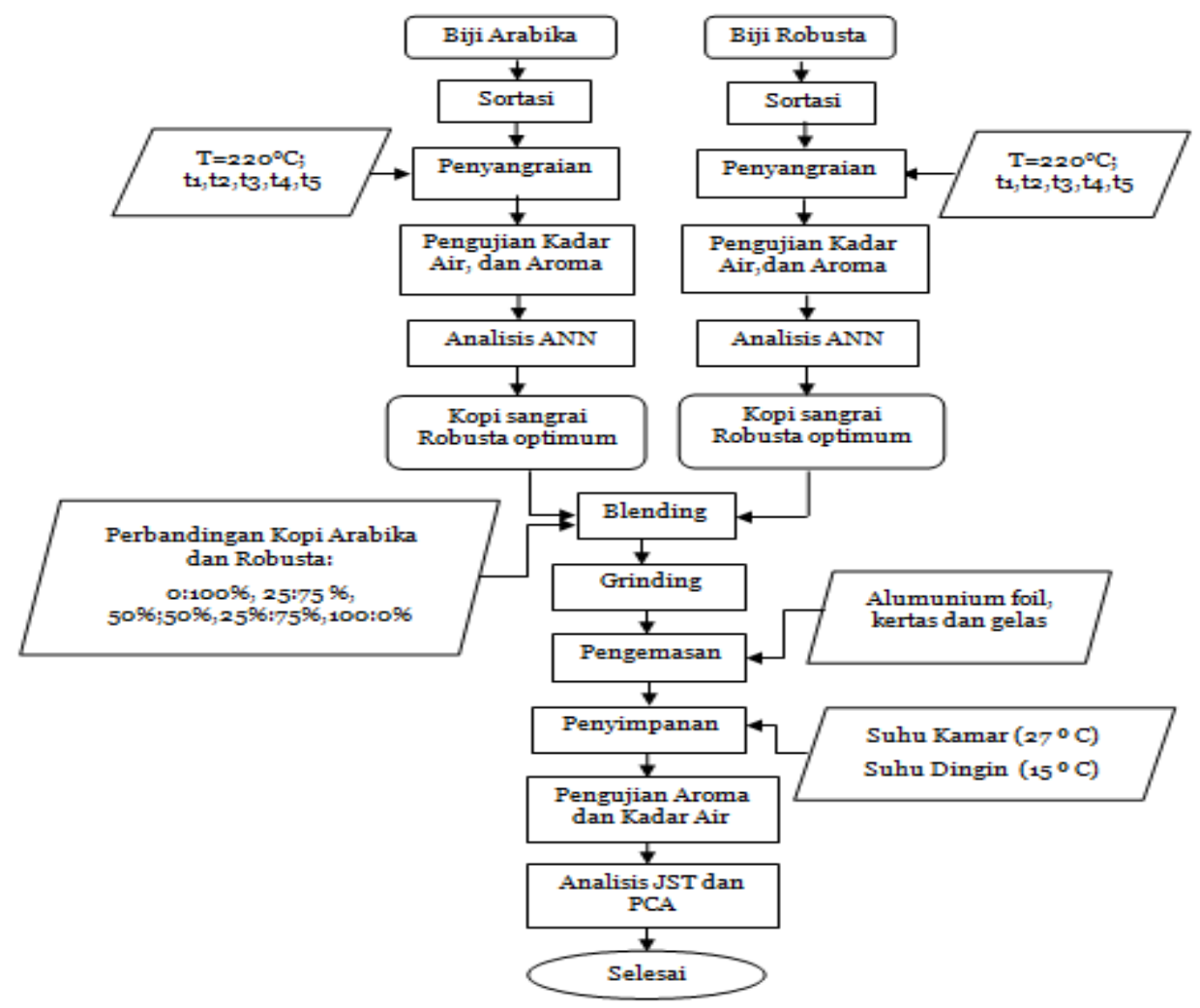

Gambar 1 Bagan Alir Penelitian 


\section{Analisis Data}

Data yang dihasilkan melalui penelitian ini dianalisis menggunakan software PCA dan Mocrosoft Exel.

\section{HASIL DAN PEMBAHASAN}

Fungsi dari PCA adalah untuk mereduksi data dari sejumlah variabel sehingga tidak terjadi redudansi dalam variabel yang dimasukkan. Dalam hal ini, redudansi berarti bahwa beberapa variabel berkorelasi satu sama lain. Hal ini dimungkinkan karena pengukuran dilakukan pada konstruksi yang sama. Karena redudansi ini, diperkirakan dapat mengurangi variabel yang diamati ke dalam sejumlah kecil komponen utama (variabel buatan) yang akan menjelaskan sebagian dari varians dalam variabel yang diamati.

Dalam penelitian yang dilakukan, terdapat variabel dari sensor aroma yang diamati secara bersamaan, yakni sensor TGS822, TGS825, TGS826 dan TGS2602. Dengan demikian, penggunaan PCA dalam penelitian ini sangat tepat guna mengurangi redudansi data yang dimasukkan. Hasil yang diharapkan adalah dapat melihat pengelompokan berdasarkan data masukan input aroma dan kadar air kopi arabika dan robusta.

Analisa yang dilakukan berupa analisa pengelompokan kualitas blending kopi Arabika dan Robusta serta pengelompokan kualitas kopi blending dengan perlakuan kemasan pada dua suhu selama penyimpanan. Hasil analisis plot PCA perlakuan blending kopi Arabika dengan Robusta dapat dilihat pada gambar 2 .

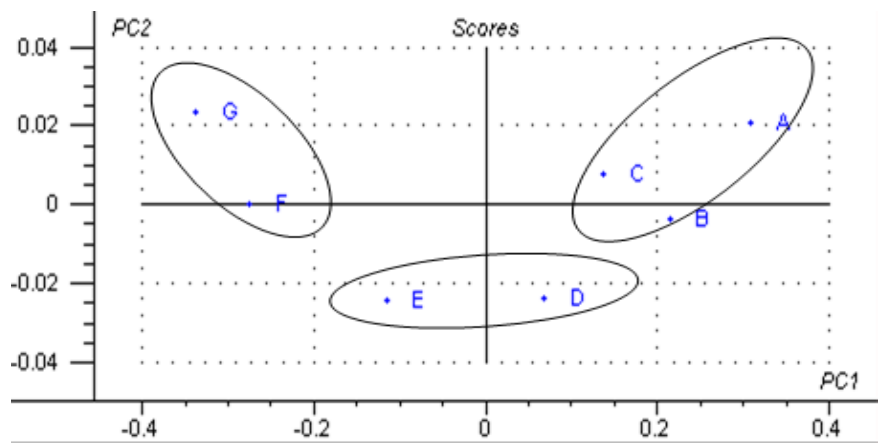

Gambar 2. Plot PCA blending kopi Arabika dan Robusta Keterangan:

$$
\begin{aligned}
& A=\text { Perbandingan Arabika:Robusta }=100 \%: 0 \% \\
& B=\text { Perbandingan Arabika:Robusta }=75 \%: 25 \% \\
& C=\text { Perbandingan Arabika:Robusta }=66,3 \%: 33,7 \% \\
& D=\text { Perbandingan Arabika:Robusta }=50 \%: 50 \% \\
& E=\text { Perbandingan Arabika:Robusta }=33,3 \%: 66,7 \% \\
& F=\text { Perbandingan Arabika:Robusta }=25 \%: 75 \% \\
& G=\text { Perbandingan Arabika:Robusta }=0 \%: 100 \%
\end{aligned}
$$

Berdasarkan Gambar 2, dapat dilihat bahwa PCA mampu mereduksi data-data yang dimasukkan sehingga dapat mengelompokkan data tersebut berdasarkan nilai sehingga tidak terjadi redudansi pada parameter sensor aroma dan kadar air. Nilai PC (Principal Component) sebesar 1,28 x 10-4.

Perlakuan A, B dan C dapat dikelompokkkan dalam satu bagian dikarenakan memiliki kedekatan nilai yang hampir sama, begitupun pada perlakuan $\mathrm{D}$ dan E, serta perlakuan F dan G dalam satu kelompok. Hal ini didasarkan pada nilai score masing-masing perlakuan yang cukup dekat. Hasil analisis PCA ini saling mendukung dengan analisis statistik.

Ploting PCA kopi selama penyimpanan dapat dilihat pada gambar 3 sampai gambar 7 .

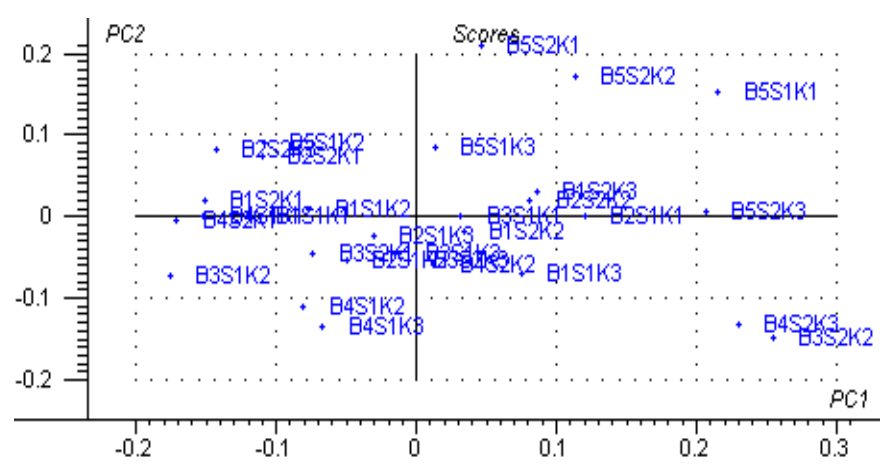

Gambar 3. Ploting PCA pengenalan jenis kopi selama penyimpanan hari pertama

Dari gambar 3. dapat dilihat bahwa pada hari pertama pengamatan, tidak begitu jelas terlihat pengelompokan data jenis kualitas kopi. Hal ini dimungkinkan karena pada hari pertama memang belum dilakukan penyimpanan yang mungkin akan merubah nilai grade kopi bubuk. Namun, jika diperhatikan secara seksama, yang membedakan antara data yang satu dengan yang lain adalah nilai blending, sedangkan untuk suhu penyimpanan baik disuhu kamar dan suhu dingin nilai skor PCA yang ditampilkan pada grafik hampir sama.

Sedangkan hasil ploting PCA setelah dilakukan penyimpanan 15 hari dapat dilihat pada gambar 4 .

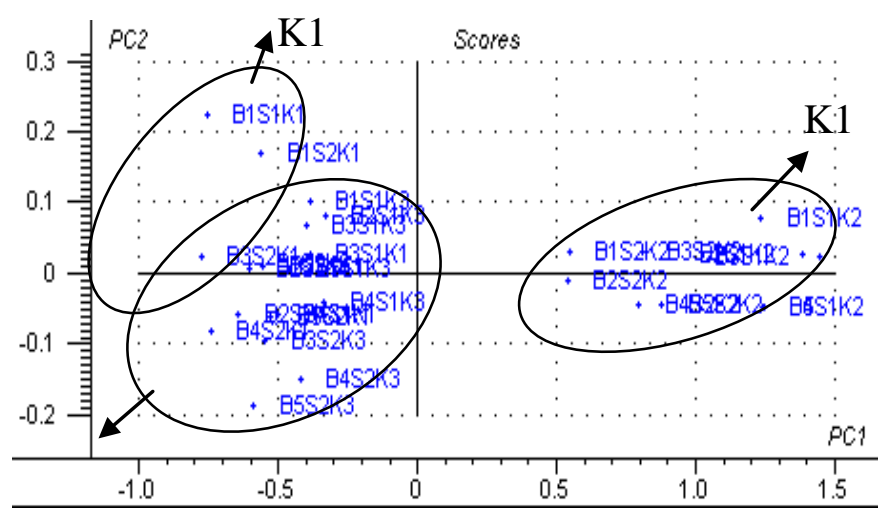

Gambar 4. Ploting PCA kualitas kopi selama penyimpanan 15 hari

Dari Gambar 4, dapat dilihat dengan cukup jelas pengaruh dari perlakuan penyimpanan dan perlakuan kemasan yang diberikan. Setelah 15 hari penyimpanan 
terlihat jelas pengelompokan data, dimana kemasan memberikan pengaruh yang signifikan. Data-data K2 yakni kemasan gelas terkelompok menjadi satu di kuadran positif (sebelah kanan). Hal ini mengindikasikan bahwa faktor kemasan yang paling memberikan pengaruh terhadap kualitas kopi selama penyimpanan. Kemasan sangat berperan dalam melindungi bahan dari pengaruh lingkungan yang dapat mempengaruhi kualitas bahan yang terdapat dalam kemasan tersebut. Penyimpangan mutu bahan pangan selama penyimpanan lebih banyak diakibatkan oleh kurang baiknya proses pengemasan yang mengakibatkan terjadinya peningkatan kadar air, yang pada akhirnya akan menurunkan aroma kopi bubuk yang disimpan

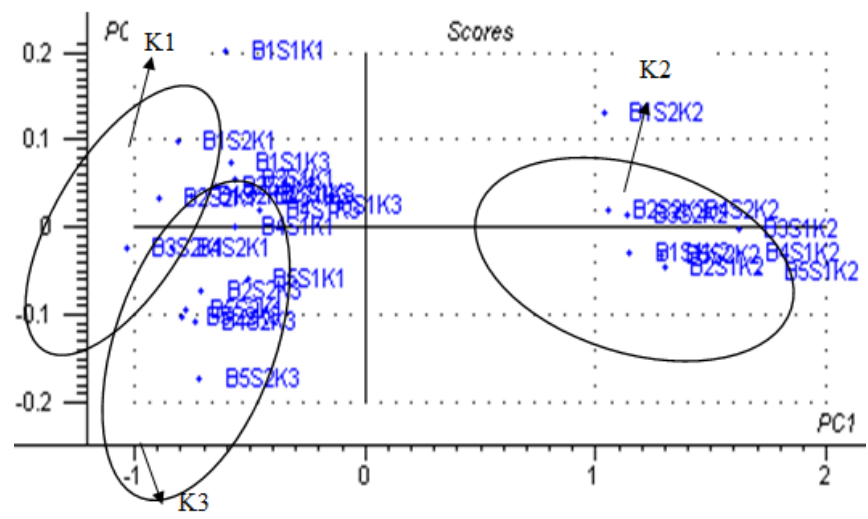

Gambar 5. Ploting PCA kualitas kopi selama penyimpanan 30 hari

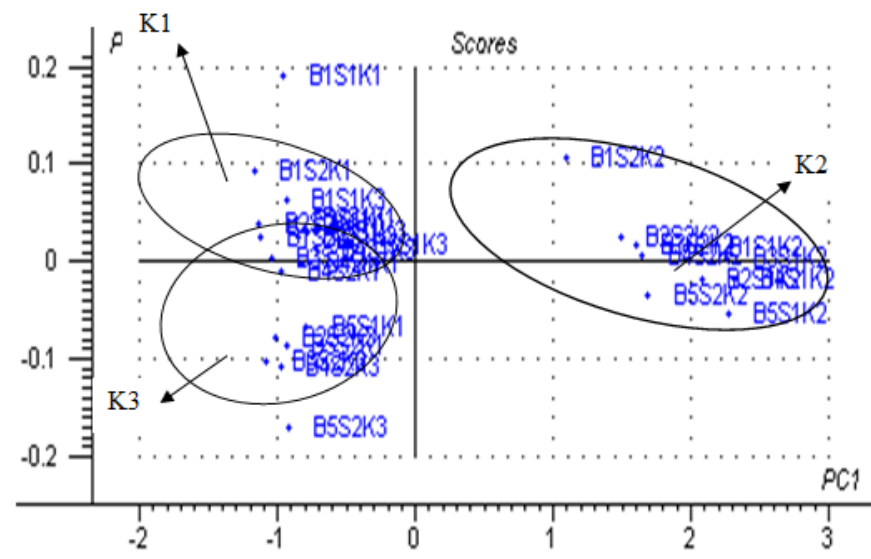

Gambar 6. Ploting PCA kualitas kopi selama penyimpanan 45 hari

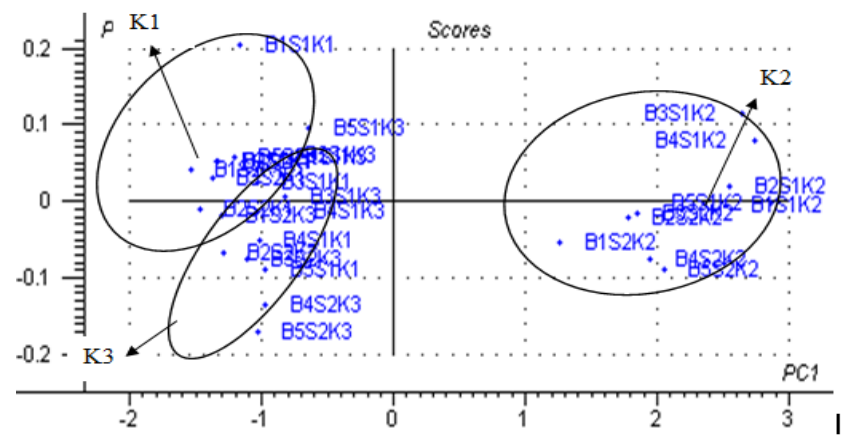

Gambar 7. Ploting PCA kualitas kopi selama penyimpanan 60 hari
Berdasarkan plot grafik PCA selama penyimpanan di atas, dapat dilihat bahwa setiap semakin lama penyimpanan nilai skor kelompok kopi dengan kemasan gelas semakin besar. Dari hari ke 15 sekitar 0,6 semakin meningkat menjadi sekitar 1-1,5 pada hari ke 30 dan pada penyimpanan hari ke-60 sekitar 1,5-2. Semakin meningkatnya nilai skor pada plot grafik dimungkinkan oleh meningkatnya nilai PC matrik PCA selama penyimpanan dengan semakin meningkatnya grade penurunan kualitas kopi. Diketahui dari pembahasan awal pada pengaruh lama penyimpanan bahwa dengan semakin lama penyimpanan maka kualitas aroma kopi semakin menurun. Begitu pun dengan menggunakan plot grafik PCA dapat dilihat bahwa dengan semakin menurunnya nilai skor PC pada plot grafik terlihat semakin meningkatnya penurunan kualitas kopi selama penyimpanan.

Nilai PC pada masing-masing lama penyimpanan dengan pemberian perlakuan suhu simpan, kemasan dan blending kopi arabika dengan robusta dapat dilihat pada tabel di bawah ini:

TABEL 1

Nilai PC (Principal Component) Analisis PCA Kopi Selama Penyimpanan

\begin{tabular}{lcc}
\hline No & Lama Penyimpanan & PC \\
\hline 1 & H0 & $9,95 \times 10-4$ \\
2 & H15 & $6,71 \times 10-4$ \\
3 & H30 & $3,94 \times 10-4$ \\
4 & H45 & $3,83 \times 10-4$ \\
5 & H60 & $3,11 \times 10-4$ \\
\hline
\end{tabular}

Nilai PC inilah yang digunakan dalam PCA guna mereduksi data input sehingga tidak terjadi redudansi data karena tujuan utama dari penggunaan PCA sebagai metode analisis adalah menghilangkan multikolinieritas sehingga tidak terjadi redudansi. Penggunaan PCA dilakukan karena data keempat sensor aroma dilakukan secara bersamaan. J adi PCA sangat tepat digunakan pada penelitian ini.

\section{SIMPULAN DAN SARAN}

\section{SIMPULAN}

1. PCA mampu mereduksi data dengan menghasilkan variable baru.

2. Nilai PC pada blending kopi arabika dan robusta sebesar $1,28 \times 10^{-4}$.

3. Hasil PCA menunjukkan terjadi penurunan kualitas kopi selama penyimpanan pada berbagai variasi kemasan

\section{SARAN}

Diperlukan penelitian lebih lanjut dengan menggunakan input parameter lain yang lebih kompleks. 


\section{DAFTAR RUJ UKAN}

[1]Kurnia R., 2009.Pengolahan dan Diversivikasi Kopi. Alphabeta. Bandung

[2]Ridwansyah, 2003. Pengolahan Kopi. Digitized by USU digital library.

[3]Yusianto. 2003. Karakteristik Fisik dan Cita Rasa Kopi Hasil Penyangraian Sistem Pemanas Langsung. Pusat Penelitian Kopi Dan kakao Indonesia. Pelita Perkebunan. Jember.

[4] Dorasi, M.E.P; 2009. Laporan Kerja Lapangan : Operasi Alat Dan Mesin Pengolahan Kopi Di PT Perkebunan Nusantara IX (Persero) Kebun Getas Salatiga. Yogyakarta.

[5] Pusat Penelitian Kopi dan Kakao Indonesia, 2007. Informasi Paket Teknologi Pengolahan Biji kopi Sekunder. Pusat Penelitian Kopi dan Kakao Indonesia. J ember.

[6]Soemartini, 2008. Principal Component Analysis (PCA) Sebagai Salah Satu Metode Untuk Mengatasi Masalah Multikolinearitas. Fakultas Matematika Dan Ilmu Pengetahuan Alam Universitas Padjadjaran J atinangor. 